JURNAL EKONOMI

EFEKTIF
ISSN : $2622-8882$, E-ISSN : 2622-9935

Jurnal Ekonomi Efektif, Vol. 2, No. 1, Oktober 2019 @Prodi Manajemen Fakultas Ekonomi Universitas

Pamulang

\title{
PENGARUH CURRENT RATIO, DEBT TO EQUITY RATIO DAN TOTAL ASSET TURNOVER TERHADAP RETURN ON EQUITY IMPLIKASINYA PADA NILAI PERUSAHAAN (PBV)
}

\author{
Neneng Khoiriah \\ nng nng@ymail.com
}

\begin{abstract}
ABSTRAK
Penelitian ini bertujuan untuk mengetahui pengaruh Current Ratio, Debt to Equity Ratio dan Total Asset Turnover terhadap Retun on Equty implikasinya pada nilai perusahaan (PBV). Hasil penelitian ini menunjukan bahwa Current ratio (X1) tidak berpengaruh signifikan terhadap Return on Equity (Y). Debt to Equity Ratio (X2) berpengaruh positif signifikan terhadap Return on Equity (Y). Total Asset Turnover (X3) berpengaruh positif signifikan terhadap Return on Equity (Y). Current Ratio (X1), Debt to Equty Ratio (X2) dan Total Asset Turnover (X3) secara simultan memiliki pengaruh yang positif dan signifikan terhadap variable Return on Equity (Y). Return on Equty (Y) berpengaruh positif signifikan terhadap Nilai Perusahaan (PBV).
\end{abstract}

\section{Kata Kunci : current ratio (CR), Debt to Equity Ratio (DER), Total Asset Turnover (TATO), Return on Equty (ROE), dan Price Book Value (PBV)}

\section{ABSTRACT}

This study aims to determine the influence of Current Ratio, Debt to Equity Ratio and Total Asset Turnover to Retun on Equty implication on firm value (PBV). The results of this study show that the Current ratio (X1) has no significant effect on Return on Equity (Y). Debt to Equity Ratio (X2) has a significant positive effect on Return on Equity (Y). Total Asset Turnover (X3) has a significant positive effect on Return on Equity (Y). Current Ratio (X1), Debt to Equty Ratio (X2) and Total Asset Turnover (X3) simultaneously have a positive and significant effect on the Return On Equity (Y) variable. Return on Equty (Y) has a significant positive effect on Corporate Value (PBV).

Keywords: current ratio (CR), Debt to Equity Ratio (DER), Total Asset Turnover (TATO), Return on Equity (ROE), and Price Book Value (PBV)

\section{PENDAHULUAN}

\section{A. Latar Belakang}

Maraknya investasi di pasar modal mengakibatkan meningkatnya jumlah investor yang beralih dari sektor perbankan ke dalam sektor pasar modal. Investor dalam menanamkan dananya membutuhkan berbagai informasi yang berguna memprediksi hasil investasinya 
dalam pasar modal. Informasi yang biasa digunakan oleh para investor dikelompokkan dalam dua hal yaitu informasi fundamental dan informasi yang bersifat teknikal.

Informasi fundamental adalah informasi yang berhubungan dengan kondisi perusahaan yang umumnya ditunjukan dalam laporan keuangan yang merupakan salah satu ukuran kinerja perusahaan. Informasi fundamental sering dilakukan untuk memprediksi harga saham. Dari laporan keuangan dapat diketahui beberapa informasi antara lain: Rasio-rasio keuangan, arus kas, serta ukuran-ukuran kinerja lainnya.

Harga saham juga menentukan nilai perusahaan, jika harga sahamnya tinggi dapat dikatakan bahwa nilai perusahaan juga baik. Memaksimalkan nilai perusahaan sama dengan memaksimalkan kemakmuran pemegang saham. Nilai perusahaan juga merupakan ukuran keberhasilan manajemen perusahaan. Dalam penelitian ini nilai perusahaan yang diambil menggunakan rasio PBV (Price Book Value), dimana rasio tersebut menggambarkan seberapa besar pasar menghargai nilai buku saham suatu perusahaan. Semakin tinggi rasio ini maka semakin besar pasar percaya akan prospek perusahaan tersebut.

Evaluasi kinerja keuangan yang digunakan untuk menilai kinerja keuangan perusahaan seperti Rasio Likuiditas, Rasio Leverage, Rasio Aktivitas dan Rasio Profitabilitas. Analisis rasio memungkinkan manajer keuangan dan pihak yang berkepentingan untuk mengevaluasi kondisi keuangan akan menunjukkan kondisi sehat tidaknya suatu perusahaan. Laba perusahaan itu sendiri dapat diukur melalui Return on Equity (ROE) perusahaan. Karena Return on Equity (ROE) mempunyai hubungan positif dengan perubahan laba. Return on Equity (ROE) digunakan untuk mengukur efektifitas perusahaan didalam menghasilkan keuntungan dengan memanfaatkan ekuitas yang dimilikinya. ROE merupakan rasio antara laba setalah pajak (EAT) dengan total ekuitas. Alat ukur kinerja suatu perusahaan yang paling populer antara penanam modal dan manajer senior adalah hasil atas hak pemegang saham adalah Return on Equity (ROE). Semakin tinggi laba perusahaan maka akan semakin tinggi Return on Equity (ROE), besarnya laba perusahaan juga dipengaruhi oleh beberapa faktor seperti CR, DER, TATO.

Faktor fundamental yang akan dipergunakan untuk memprediksi profitabilitas adalah rasio likuiditas, leverage, activity, dan profitabilitas. Rasio likuiditas diwakili oleh Current Ratio, Rasio Leverage diwakili oleh Debt to Equity Ratio, Rasio Activity diwakili oleh Total Assets Turnover. Pemilihan industri manufaktur sebagai objek dalam penelitian ini untuk melakukan pengujian lebih lanjut temuan - temuan empiris mengenai rasio keuangan, khususnya yang menyangkut kegunaannya dalam pencapaian tingkat keuntungan yang diperoleh perusahaan. Perusahaan yang dipilih dalam penelitian ini adalah perusahaan manufaktur khususnya industri makanan dan minuman yang terdaftar di BEI tahun 2007 2016, mengingat kondisi ekonomi yang selalu mengalami perubahan, maka dapat mempengaruhi kondisi perusahaan yang dapat dilihat dari labanya. Laba perusahaan yang harusnya meningkat, justru sebaliknya mengalami penurunan maka akan mengganggu aktivitas operasional perusahaan. Subsektor makanan dan minuman merupakan sektor yang dapat dikatakan dinamis, terbukti dengan banyaknya perusahaan yang terdaftar di BEI dan adanya beberapa perusahaan yang listed dan delisted dari BEI. Dalam rasio keuangan perusahaan dapat berubah-ubah dari waktu ke waktu.

Berdasarkan latar belakang tersebut penulis tertarik untuk melakukan penelitian yang berjudul "PENGARUH CURRENT RATIO, DEBT TO EQUITY RATIO dan TOTAL ASSET TURNOVER TERHADAP RETURN ON EQUITY IMPLIKASINYA PADA NILAI PERUSAHAAN (PBV)". (Perusahaan Industri Manufaktur sektor Cunsumer Goods subsektor Makanan dan Minuman Yang Terdaftar Di Bursa Efek Indonesia periode 20072016). 


\section{B. Tujuan Penelitian}

Berdasarkan rumusan masalah diatas, tujuan yang ingin dicapai dari pelaksanaan penelitian ini adalah untuk :

1. Mengetahui pengaruh Current Ratio terhadap Return on Equty pada industri consumer goods subsektor makanan dan minuman yang terdaftar di BEI periode 2007-2016.

2. Mengetahui pengaruh Debt to Equity Ratio terhadap Retun on Equity pada industri bidang consumer goods subsektor makanan dan minuman yang terdaftar di BEI periode 2007-2016.

3. Mengetahui pengaruh Total Asset Turnover terhadap Return on Equity pada indusrti consumer goods subsektor makanan dan minuman yang terdaftar di BEI periode 20072016.

4. Mengetahui pengaruh Current Ratio, Debt to Equity Ratio dan Total Asset Turnover terhadap Return on Equty pada industri consumer goods subsektor makanan dan minuman yang terdaftar di BEI periode 2007-2016.

5. Mengetahui pengaruh Return on Equity terhadap Nilai Perusahaan (Price book value) pada industri consumer goods subsektor makanan dan minuman yang terdaftar di BEI periode 2007-2016.

\section{TINJAUAN PUSTAKA}

\section{A. Rasio Keuangan}

\section{Pengertian Rasio Keuangan}

Rasio keuangan merupakan salah satu jenis alat ukur yang sering digunakan perusahan untuk menganalisis baik atau buruknya kondisi atau posisi keuangan suatu perusahaan dari satu periode ke periode berikutnya. Pengertian rasio keuangan menurut Abdul Halim (2013: 53) yaitu perbandingan dari pos-pos atau elemen laporan keuangan yang dalam hal ini adalah neraca dan laporan laba rugi.

\section{Jenis-Jenis Rasio Keuangan}

Menurut Irham Fahmi (2012: 65) rasio keuangan dikelompokkan menjadi enam jenis, yaitu:

a) Rasio Likuiditas

Menurut Riyanto (2011:25) mengemukakan "Likuiditas adalah kemampuan perusahaan atau badan usaha untuk memenuhi kewajiban finansialnya yang harus segera dipenuhi”.

b) Rasio Solvabilitas (Leverage)

Menurut Munawir (2011:35) mengemukaan "Rasio Solvabilitas menunjukan kemampuan perusahaan untuk memenuhi kewajiban keuangannya apabila perusahaan dilikuidasi, baik kewajiban keuangan jangka pendek maupun jangka panjang”. Rasio ini disebut juga rasio Leverage yaitu mengukur perbandingan dana yang disediakan oleh pemiliknya dengan dana yang dipinjma dari kreditur perusahaan tersebut.

c) Rasio Aktivitas

Rasio ini menggambarkan penggunaan sumber daya yang dimiliki perusahaan guna menunjang aktivitasnya. Tujuan dari rasio ini adalah untuk mengetahui kemampuaan perusahaan dalam memaksimalkan aktivitas operasional suatu perusahaan. Secara umum rasio aktivitas ada empat, yaitu inventory turnover (perputaran persediaan), rata-rata periode pengumpulan piutang, fixed asset turnover (perputaran aktiva tetap), dan total asset turnover (perputaran total asset).

d) Rasio Profitabilitas

Menurut Riyanto (2011:35) mendefinisikan "Profitabilitas merupakan kemampuan suatu perusahaan untuk mengahsilkan laba selama suatu periode tertentu. 
e) Rasio Pertumbuhan

Rasio ini mengukur kemampuan perusahaan dalam mempertahankan posisinya di dalam industri dan dalam perkembangannya ekonomi secara umum.

f) Rasio Nilai Pasar

Rasio ini menggambarkan kondisi yang terjadi di pasar. Secara umum rasio ini ada lima, yaitu earnings per share (EPS), price earnings ratio (PER), Price Book Value (PBV), dividend yield, dan dividend payout ratio.

\section{B. Return On Equity}

Profitabilitas adalah menggambarkan kemampuan perusahaan mendapatkan laba melalui semua kemampuan dan sumber yang ada seperti kegiatan penjualan, kas, modal, jumlah karyawan, jumlah cabang dan sebagainya. Rasio profitabilitas yang menggambarkan kemampuan perusahaan menghasilkan laba dapat disebut juga operating ratio. Keuntungan yang akan diraih dari investasi yang akan ditanamkan merupakan pertimbangan utama bagi sebuah perusahaan dalam rangka pengembangan bisnisnya. Disamping itu sehubungan dengan masalah dari ketidakpastian dari kondisi yang akan dihadapi maka besar investasi yang ditanamkan harus diperhitungkan dalam pengambilan kebutuhan dana.

Return on Equity dapat dirumuskan sebagai berikut :

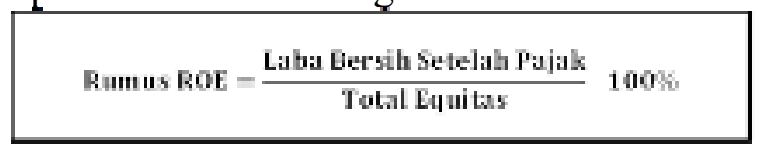

\section{Current Ratio}

Current Ratio merupakan rasio yang menunjukan bagaimana kewajiban lancar ditutupi oleh aset yang akan diubah menjadi kas dalam waktu deket. Current ratio merupakan salah satu indikator dari rasio likuditas yang paling umum digunakan untuk menggambarkan kemampuan perusahaan dalam memenuhi kewajiban jangka pendeknya yang telah jatuh tempo. Menurut Weygandt (2013:397), current ratio merupakan pengukuran yang digunakan secara luas untuk mengevaluasi likuidasi perusahaan dan kemampuan membayar hutang jangka pendek.

\section{Pengukuran Current Ratio}

Perhitungan Current Ratio menurut Brigham dan Houston (2012: 134) sebagai berikut:

$$
\text { Rumus Curreuc fazio }=\frac{\text { Nktiva Lancar }}{\text { Kewajibu Lancar }} 100 \%
$$

Menurut Subramayan (2013: 242), aset lancar (current asset) adalah kas dan aset lain yang secara wajar dapat direalisasikan sebagai kas atau dijual atau digunakan selama setahun (atau dalam siklus operasi normal perusahaan jika lebih dari stau tahun). Aset lancar meliputi kas, efek (surat berharga atau sekuritas) yang jatuh tempo dalam satu tahun fiskal ke depan, piutang, persediaan dan beban dibayar dimuka.

\section{E. Debt to Equity Ratio}

\section{Pengertian Debt to Equity Ratio}

Debt to Equity Ratio menunjukan berapa rupiah modal sendiri yang disediakan untuk membayar hutang (Abdul Halim: 56). Debt to equity ratio berguna untuk mengetahui jumlah dana yang sediakan piminjam (kreditor) dengan pemilik perusahaan, dengan kata lain rasio ini untuk mengetahui setiap rupiah modal sendiri yang dijadikan jaminan hutang (Kasmir, 2010: 112). Jadi dapat disimpulkan Debt to equity ratio menunjukan bagaimana kemampuan perusahaan menggunakan modal yang ada dalam 
memenuhi kewajibannya.

\section{Pengukuran Debt to Equity Ratio}

Perhitungan Debt to Equity Ratio menurut Kasmir (2010: 124) sebagai berikut:

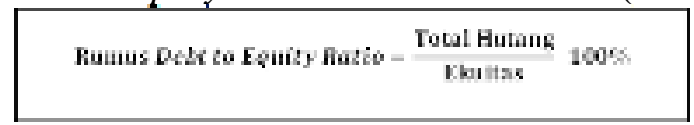

Kewajiban merupakan hutang untuk mendapatkan pendanaan yang membutuhkan pembayaran di masa depan dalam bentuk uang, jasa atau aset lainnya. Kewajiban umumnya dilaporkan sebagai kewajiban lancar dan kewajiban tidak lancar (Subramanyam 2014: 16).

\section{Total Asset Turnover}

Total Asset Turnover merupakan rasio yang digunakan untuk mengukur perputaran semua aktiva yang dimiliki perusahaan, kemudian juga mengukur berapa jumlah penjualan yang diperoleh dari tiap rupiah aktiva (Kasmir, 2010: 114). Menurut lukman (2011: 62), Total Asset Turnover menunjukan tingkat efesiensi penggunaan keseluruhan aktiva perusahaan di dalam menghasilkan volume penjualan tertentu Pengukuran Total Asset Turnover berikut :

Perhitungan Total Asset Turnover menurut Brigham (2012: 139) adalah sebagai

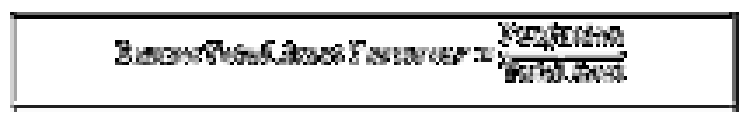

\section{F. Nilai Perusahaan}

\section{Pengertian Nilai Perusahaan}

Nilai perusahaan sangat penting karena dengan nilai perusahaan yang tinggi akan diikuti oleh tingginya kemakmuran pemegang saham. Semakin tinggi harga saham semakin tinggi pula nilai perusahaan. Nilai perusahaan yang tinggi menjadi keinginan para pemilik perusahaan. Sebab dengan nilai yang tinggi menunjukan kemakmuran pemegang saham juga tinggi.

\section{Pengukuran Nilai Perusahaan}

Price to Book Value menggambarkan seberapa besar pasar menghargai nilai buku saham suatu perusahaan. Semakin tinggi rasio ini berarti pasar percaya akan prospek perusahaan tersebut. PBV juga menunjukan seberapa jauh suatu perusahaan mampu menciptakan nilai perusahaan yang relatif terhadap jumlah modal yang diinvestasikan. Perhitungan Price Book Value :

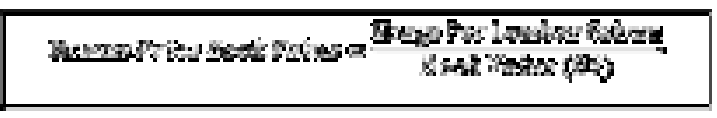

Book Value (BV) adalah nilai buku per lembar saham di dapat dengan rumus :

\begin{tabular}{|c|}
\hline 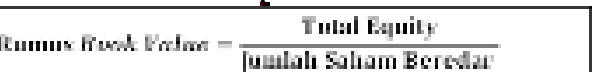 \\
\hline
\end{tabular}

\section{G. Kerangka Pemikiran}

Kerangka berfikir merupakan model konseptual tentang bagaimana teori berhubungan dengan berbagai faktor yang telah diidentifikasi sebagai masalah yang penting, Sugiyono (2014:93) 


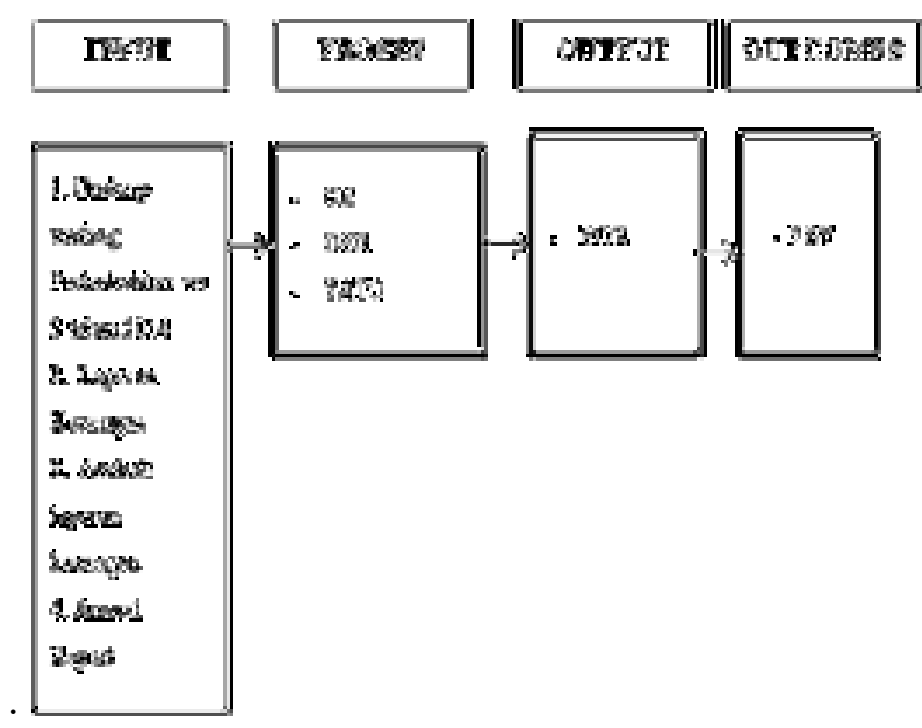

Gambar 1.1 Kerangka Berfikir

\section{H. Hipotesis Penelitian}

Berdasarkan pada berbagai penelitian sebelumnya dan kerangka pemikiran yang dikembangkan maka dirumuskan hipotesis dalam penelitian ini sebagai berikut :

$\mathrm{H} 1=$ Terdapat pengaruh yang signifikan antara Current Ratio (CR) terhadap Return on Equity (ROE)

$\mathrm{H} 2$ = Terdapat pengaruh positif yang signifikan antara Debt to Equity Ratio terhadap Return on Equity (ROE)

H3 = Terdapat pengaruh positif signifikan Total Asset Turnover (TATO) terhadap Return on Equity (ROE)

H4 = CR, DER dan TATO secara simultan memiliki pengaruh positif yang signifikan terhadap Return on Equity (ROE)

H5 = Terdapat pengaruh positif yang signifikan antara Return on Equity (ROE) terhadap Nilai Perusahaan (PBV)

\section{METODE PENELITIAN}

Jenis penelitian ini adalah penelitian kuantitatif, karena variabel yang digunakan dalam penelitian ini, baik variabel independen yaitu current ratio, total assets turnover, debt to equity Ratio, variabel dependen yaitu return on equity, dan Nilai Perusahaan (Price Book Value) sebagai variabel Z. Metode pengujian data menggunakan pengujian Model Regresi Data Panel (pendekatan Common Effect, pendekatan Fixed Effect, dan pendekatan Random Effect), Uji Hipotesis dan Koefesien Determinasi.

\section{HASIL PENELITIAN DAN PEMBAHASAN}

A. Pengujian Model Regresi Data Panel Variabel Current Ratio (CR), Debt to Equity Ratio dan Total Asset Turnover (TATO) terhadap Return on Equity (ROE)

Model yang digunakan dalam penelitian ini adalah pengolahan data menggunakan regresi data panel dengan alternative 3 metode, yaitu Common Effect Model (CEM), Fixed Effect Model (FEM) dan Random Effect Model (REM).

Hal pertama yang harus dilakukan adalah menguji model regresi manakah yang paling tepat digunakan. Pengujian akan dilakukan untuk menguji spesifikasi model dan kesesuaian teori-teori dengan kenyataa. Pengolahan data dilakukan secara elektronik dengan menggunakan aplikasi eviews 9. 


\section{Uji Chow}

Berikut ini merupakan Uji Chow CR, DER dan TATO terhadap ROE dapat dilihat pada tebel berikut:

Tabel 4.1 Uji Chow CR, DER dan TATO terhadap ROE

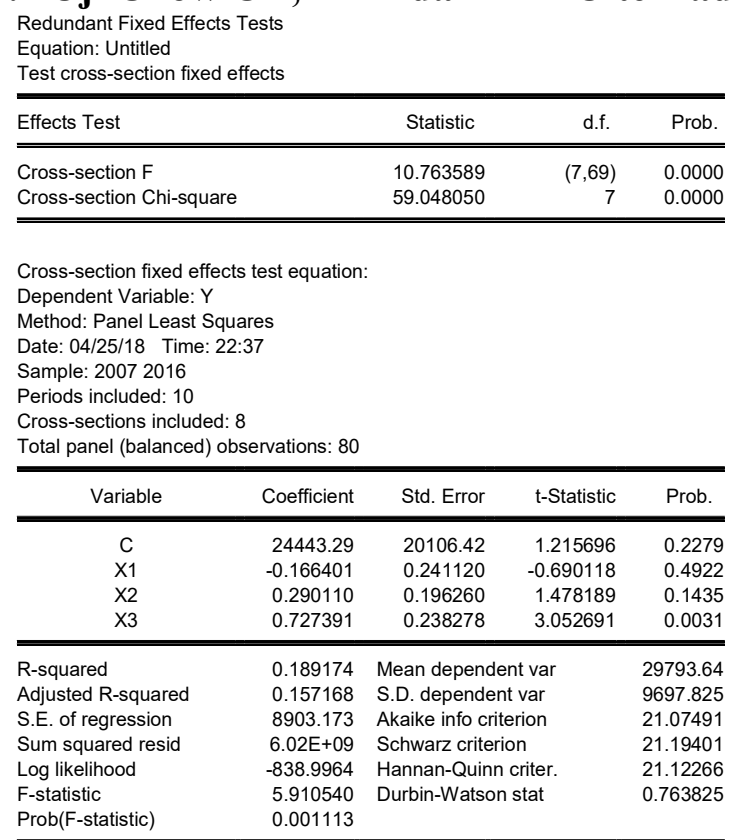

Pada tabel 4.1 uji chow diatas dapat dilihat CR, DER dan TATO terhadap ROE bahwa nilai probalilitas (Prob) cross section $\mathrm{F}$ adalah $0.0000<0,05$, maka Ho ditolak atau dengan kata lain H1 diterima. Sehingga disimpulkan bahwa fixed Effect Model (FEM) lebih cepat dibandingkan dengan Common Effect Model (CEM).

\section{Uji Hausman}

Hasil pengujian Hausman dalam penelitian ini adalah sebagai berikut:

Table 4.2 Hasil Uji Hausman CR, DER, dan TATO terhadap ROE

\begin{tabular}{|c|c|c|c|c|}
\hline 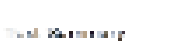 & & $\begin{array}{l}: \because x_{1} \\
x_{A 1}\end{array}$ & $:: s_{1}+11$ & Aut \\
\hline 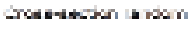 & & Q246-6 & 2 & $-\sin \theta$ \\
\hline \multicolumn{5}{|c|}{ 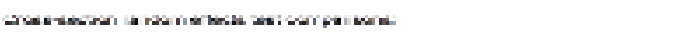 } \\
\hline Sholkely & non- & nerenter & $\sin t \boldsymbol{P}$, & $\operatorname{roch}$ \\
\hline $\begin{array}{l}x 1 \\
x: 2 \\
x:\end{array}$ & 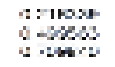 & 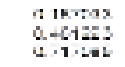 & 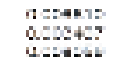 & 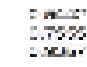 \\
\hline \multicolumn{5}{|c|}{ 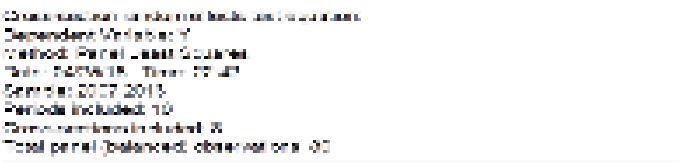 } \\
\hline Strateres & $-a n+x+\infty$ & Dat Prose & $=0+1+\pi$ & $\mathrm{r}, \mathrm{H}$ \\
\hline $\begin{array}{l}4: \\
x ! \\
x= \\
x=\end{array}$ & 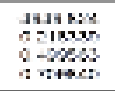 & 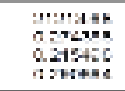 & 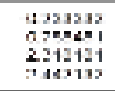 & 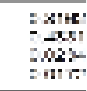 \\
\hline \multicolumn{5}{|c|}{ 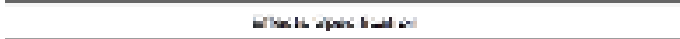 } \\
\hline \multicolumn{5}{|c|}{ 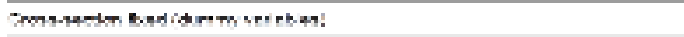 } \\
\hline 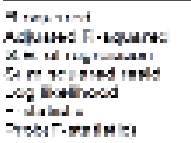 & 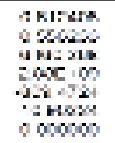 & 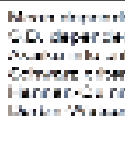 & 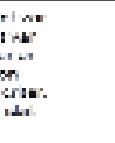 & 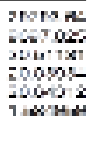 \\
\hline
\end{tabular}

Pada tabel 4.2 hasil Uji Hausman CR, DER, dan TATO terhadap ROE bahwa nilai probabilitas (Prob) cross section $\mathrm{F}$ adalah $0.9280>0,05$ (ditentukan dari awal sebagai 
tingkat atau alpha). Maka H1 ditolak atau dengan kata lain Ho diterima, sehingga disimpulkan bahwa model Random Effect Model (REM) lebih tepat dibandingkan dengan Fixed Effect Model (FEM).

3. Uji Langrange Multiplier (LM)

Hasil pengujian Langrange Multiplier (Uji LM) dalam penelitian ini menggunakan aplikasi eviews 9 dengan hasil adalah sebagai berikut:

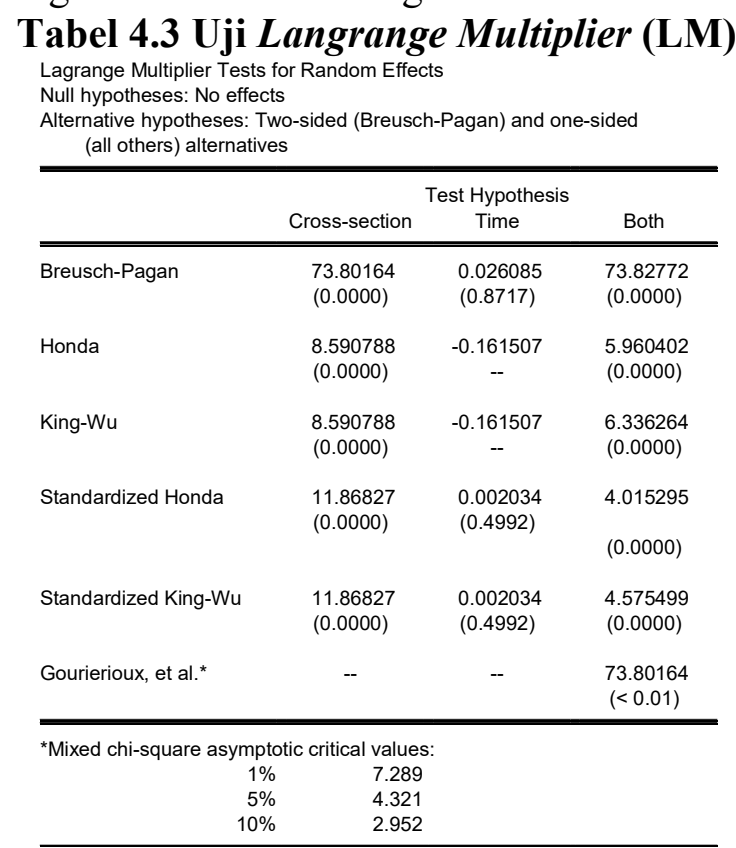

Dari tabel 4.3 diatas dapat dilihat Nilai $\mathrm{P}$ value ditunjukan oleh angka yang dibawah yaitu sebesar 0.0000 dimana nilainya kurang dari 0,05 sehingga Langrange Multiplier Test ini menunjukan bahwa $\mathrm{H} 1$ diterima dan Ho di tolak yang berarti metode estimasi terbaik adalah Random Effect Model (REM).

\section{B. Pengujian Model Regresi Data Panel Variabel Return on Equity (ROE) terhadap Nilai Perusahaan (PBV)}

\section{Uji Chow Y-Z}

Hasil pengujian Uji Chow dalam penelitian ini menggunakan eviews 9 dengan hasil sebagai berikut:

Tabel 4.4 Uji Chow ROE

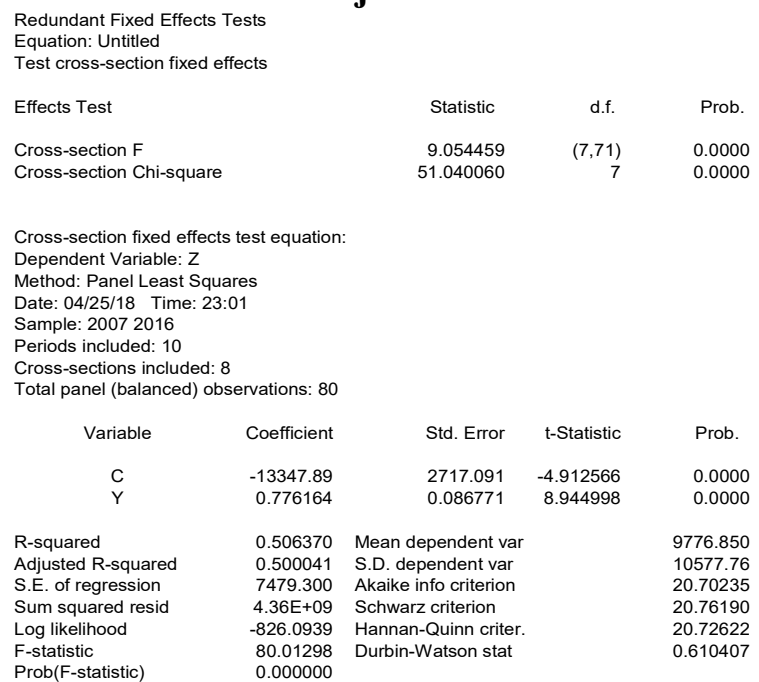


Pada tabel 4.4 hasil Uji Chow ROE terhadap Nilai perusahaan (PBV) bahwa nilai probabilitas (Prob) cross section $\mathrm{F}$ adalah $0,0000<0,05$ (ditentukan dari awal sebagai tingkat atau alpha). Maka H0 ditolak atau dengan kata lain H1 diterima, Sehingga disimpulkan bahwa model fixed Effect Model (FEM) lebih cepat dibandingkan dengan model Common Effect Model (CEM).

\section{Uji Hausman $\mathbf{Y}-\mathrm{Z}$}

Tabel 4.5 Uji Hausman Y $-Z$

\begin{tabular}{|c|c|c|c|c|}
\hline Test Summary & & $\begin{array}{l}\text { Chi-Sq. } \\
\text { Statistic }\end{array}$ & Chi-Sq. d.f. & Prob. \\
\hline Cross-section random & & 2.315221 & 1 & 0.1281 \\
\hline \multicolumn{5}{|c|}{ Cross-section random effects test comparisons: } \\
\hline Variable & Fixed & Random & $\operatorname{Var}($ Diff.) & Prob. \\
\hline $\mathrm{Y}$ & 0.541606 & 0.593052 & 0.001143 & 0.1281 \\
\hline \multicolumn{5}{|c|}{$\begin{array}{l}\text { Cross-section random effects test equation: } \\
\text { Dependent Variable: } Z \\
\text { Method: Panel Least Squares } \\
\text { Date: } 04 / 25 / 18 \text { Time: } 23: 04 \\
\text { Sample: } 2007 \text { 2016 } \\
\text { Periods included: } 10 \\
\text { Cross-sections included: } 8 \\
\text { Total panel (balanced) observations: } 80\end{array}$} \\
\hline Variable & Coefficient & Std. Error & t-Statistic & Prob. \\
\hline $\begin{array}{l}\mathrm{C} \\
\mathrm{Y}\end{array}$ & $\begin{array}{r}-6359.573 \\
0.541606\end{array}$ & $\begin{array}{l}2985.238 \\
0.097889\end{array}$ & $\begin{array}{r}-2.130341 \\
5.532869\end{array}$ & $\begin{array}{l}0.0366 \\
0.0000\end{array}$ \\
\hline \multicolumn{5}{|c|}{ Effects Specification } \\
\hline \multicolumn{5}{|c|}{ Cross-section fixed (dummy variables) } \\
\hline $\begin{array}{l}\text { R-squared } \\
\text { Adjusted R-squared } \\
\text { S.E. of regression } \\
\text { Sum squared resid } \\
\text { Log likelihood } \\
\text { F-statistic } \\
\text { Prob(F-statistic) }\end{array}$ & $\begin{array}{l}0.739192 \\
0.709805 \\
5698.217 \\
2.31 E+09 \\
-800.5739 \\
25.15381 \\
0.000000\end{array}$ & $\begin{array}{l}\text { Mean depend } \\
\text { S.D. depende } \\
\text { Akaike info cri } \\
\text { Schwarz crite } \\
\text { Hannan-Quinr } \\
\text { Durbin-Watso }\end{array}$ & $\begin{array}{l}\text { nt var } \\
\text { t var } \\
\text { erion } \\
\text { on } \\
\text { criter. } \\
\text { stat }\end{array}$ & $\begin{array}{l}9776.850 \\
1057.76 \\
20.23935 \\
20.50733 \\
20.34679 \\
0.937752\end{array}$ \\
\hline
\end{tabular}

Pada tabel 4.4 hasil Uji Hausman ROE terhadap Nilai Perusahaan (PBV) bahwa nilai probabilitas (Prob) cross section $\mathrm{F}$ adalah $0.1281>0,05$ (ditentukan dari awal sebagai tingkat atau alpha). Maka $\mathrm{H} 1$ ditolak atau dengan kata lain Ho diterima, sehingga disimpulkan bahwa model Random Effect Model (CEM) lebih tepat dibandingkan dengan Fixed Effect Model (FEM).

\section{Uji Langrange Multiplier (Uji LM)}

Hasil pengujian Langrange Multiplier (Uji LM) dalam penelitian ini menggunakan aplikasi eviews 9 dengan hasil adalah sebagai berikut:

\section{Tabel 4.6 Uji Langrange Multiplier (Uji LM)}

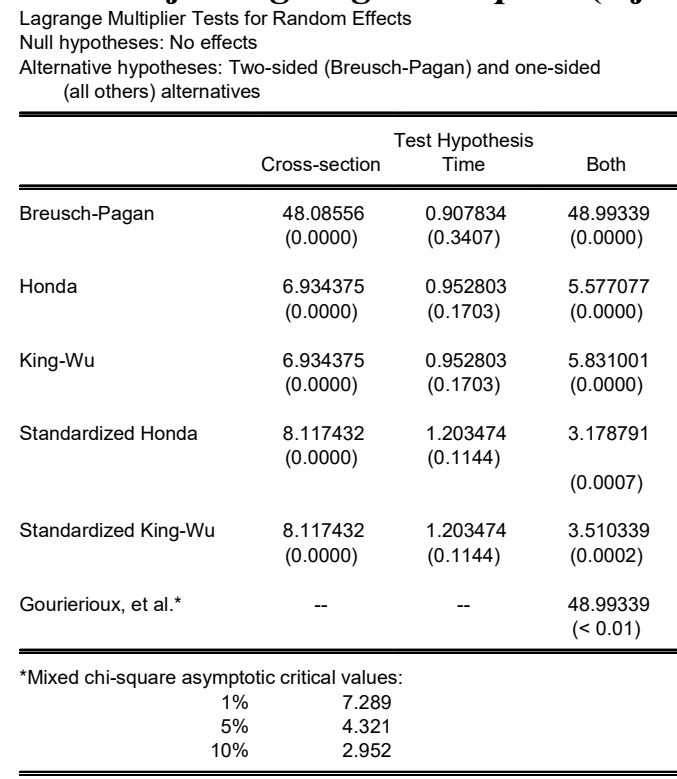


Dari tabel 4.6 diatas dapat dilihat Nilai P-Value ditunjukan oleh angka yang dibawah yaitu sebesar 0,0000 dimana nilainya kurang dari 0,05. Sehingga Langrange Multiplier Test ini menunjukan bahwa H1 diterima dan Ho ditolak yang berarti metode estimasi terbaik adalah Random Effect Model (REM).

\section{Pengaruh Current Ratio (CR) terhadap Return on Equity (ROE)}

Hasil pengujian analisis regresi data panel secara parsial menunjukan hasil t-hitung variabel independen $\mathrm{CR}$ adalah sebesar -0.350255 sementara t-tabel dengan $\alpha=5 \%$ dan $\mathrm{df}=$ $(\mathrm{n}-\mathrm{k}=80-5=75: 0,05)=1,992$. Maka t hitung lebih kecil daripada t table $(-0.350255<$ 1,992) dengan nilai signifikansi $>0,05$ terlihat pada probabilitas Current Ratio (CR) sebesar 0.7271 lebih besar dari 0,05 maka dapat diartikan Ho diterima dan H1 ditolak. Kondisi tersebut menunjukan bahwa variabel CR (Current Ratio) tidak berpengaruh signifikan terhadap ROE (Return on Equity).

\section{Pengaruh Debt to Equity Ratio (DER) terhadap Return on Equity (ROE)}

Hasil pengujian analisis regresi data panel secara parsial menunjukan hasil t-hitung variabel independen DER adalah sebesar 2.135365 sementara t-tabel dengan $\alpha=5 \%$ dan $\mathrm{df}=$ $(\mathrm{n}-\mathrm{k}=80-5=75 ; 0,05)=1,992$. Maka $\mathrm{t}$ hitung lebih besar darpada $\mathrm{t}$ tabel $(2.135365>$ 1,992) dengan nilai signifikansi $<0,05$ terlihat pada probabilitas Debt to Equity Ratio (DER) sebesar 0.0359 lebih kecil dari 0,05 maka dapat diartikan Ho ditolak dan H1 diterima. Kondisi tersebut menunjukan bahwa variabel DER (Debt to Equity Ratio) berpengaruh positif signifikan terhadap ROE (Return on Equity).

\section{E. Pengaruh Total Asset Turnover (TATO) terhadap Return on Equity (ROE)}

Berdasarkan tabel 4.20 hasil pengujian analisis regresi data panel secara parsial menunjukan hasil t-hitung variabel independen TATO adalah sebesar 2.592864 sementara ttabel dengan $\alpha=5 \%$ dan $\mathrm{df}=(\mathrm{n}-\mathrm{k}=80-5=75 ; 0,05)=1,992$. Maka t hitung lebih besar darpada $t$ tabel $(2.592864>1,992)$ dengan nilai signifikansi $<0,05$ terlihat pada probabilitas Total Asset Turnover (TATO) sebesar 0.0114 lebih kecil dari 0,05 maka Ho ditolak dan H1 diterima. Kondisi tersebut menunjukan bahwa variabel TATO (Total Asset Turnover) berpengaruh positif signifikan terhadap ROE (Return on Equity).

\section{F. Uji Simultan (Uji F)}

Adapun untuk menentukan besarnya $\mathrm{F}$ tabel dicari dengan ketentuan tingkat signifikan $(\alpha)=5 \%$ dan df1 $(\mathrm{k}-1)=(4-1)=3$ dan df $2(\mathrm{n}-\mathrm{k})=(80-4)=76 \mathrm{~F}$ tabel sebesar 2,72 .

Berdasarkan tabel 4.21Hasil pengujian diatas pengaruh CR (Current Ratio), DER (Debt to Equity Ratio), TATO (Total Asset Turnover) terhadap ROE (Return on Equity), didapatkan nilai $\mathrm{F}$ hitung lebih besar dari $\mathrm{F}$ table $4.536702>2,72$ dan ditunjukan juga dengan nilai probabilitasnya lebih kecil dari tingkat signifikan $0,05(0.005585<$

0,05 ), jadi Ho ditolak dan H1 diterima. Dapat disimpulkan bahwa variabel CR (Current Ratio), DER (Debt to Equiy Ratio), TATO (Total Asset Turnover) secara bersama-sama (simultan) memiliki pengaruh positif signifikan terhadap variabel ROE (Return on Equity).

Pada tabel 4.21 diatas maka diperoleh persamaan model regresi antara variabel Current Ratio (CR), Debt to Equity Ratio (DER) dan Total Asset Turnover (TATO) terhadap Return on Equity (ROE) yaitu sebagai berikut:

$$
\mathrm{Y}=-1559.012+0.167033(\mathrm{X} 1)+0.481226(\mathrm{X} 2)+0.717085(\mathrm{X} 3)
$$




\section{G. Uji Hipotesis Return on Equity (ROE) terhadap Nilai Perusahaan (PBV)}

Berdasarkan tabel 4.22 hasil pengujian analisis regresi data panel secara parsial menunjukan hasil t-hitung variabel Return on Equity adalah sebesar 6.455733 sementara t-tabel dengan $\alpha=5 \%$ dan $\mathrm{df}=(\mathrm{n}-\mathrm{k}=80-5=75 ; 0,05)=1,992$. Maka $\mathrm{t}$ hitung lebih besar daripada $\mathrm{t}$ table $(6.455733>1,992)$ dengan nilai signifikansi $<0,05$ terlihat pada probabilitas sebesar $0.0000<0,05$ maka Ho ditolak dan $\mathrm{H} 1$ diterima. Kondisi tersebut menunjukan bahwa variabel ROE (Return on Equiy) berpengaruh positif signifikan terhadap Nilai Perusahaan (PBV). Maka diperoleh persamaan model regresi antara variabel Return on Equity terhadap Nilai perusahaan (Price Book Value) yaitu sebagai berikut:

$$
\mathrm{Z}=-7892.331+0.593052(\mathrm{Y})
$$

\section{H. Koefisien Determinasi (Adjusted R-Square)}

R-squared adalah sebesar 0.151881 yang berarti $15,19 \%$ variasi variabel probabilitas (Return on Equity) dapat dijelaskan oleh tiga variabel independen yang ada. Sebesar 84,81\% probabilitas (Return on Equity) dijelaskan oleh variabel lain yang tidak diamati dalam penelitian ini.

\section{KESIMPULAN DAN SARAN}

\section{A. Kesimpulan}

Berdasarkan hasil penelitian dan pembahasan yang telah dilakukan dalam penelitian mengenai "Pengaruh Current Ratio, Debt to Equity Ratio, Total Asset Turnover terhadap Return on Equity implikasinya terhadap Nilai Perusahaan (PBV) pada perusahaan makanan dan minuman di BEI 2007-2016", dapat ditarik kesimpulan sebagai berikut:

1. Current ratio (X1) tidak berpengaruh signifikan terhadap Return on Equity (Y). Dimana hasil pengujian $t$ hitung lebih kecil darpada $t$ table $(-0,350255<1,992)$ dengan nilai signifikansi 0,7271 >0,05 maka Ho diterima dan H1 ditolak.

2. Debt to Equity Ratio (X2) berpengaruh positif signifikan terhadap Return on Equity (Y). Dimana hasil pengujian $t$ hitung lebih besar daripada t table $(2.135365>1,992)$ dengan nilai signifikansi $0.0359<0,05$ maka Ho ditolak dan $\mathrm{H} 1$ diterima.

3. Total Asset Turnover (X3) berpengaruh positif signifikan terhadap Return on Equity (Y). $\mathrm{t}$ hitung lebih besar daripada $\mathrm{t}$ tabel $(2.592864>1,992)$ dengan nilai signifikansi 0.0114 $<0,05$ maka Ho ditolak dan H1 diterima.

4. Current Ratio (X1), Debt to Equty Ratio (X2) dan Total Asset Turnover (X3) secara simultan memiliki pengaruh positif signifikan terhadap variable Return on Equity (Y). dimana hasil pengujian $\mathrm{F}$ hitung lebih besar dari $\mathrm{F}$ table $4.536702>2,72$ dan ditunjukan juga dengan nilai probabilitasnya lebih kecil dari tingkat signifikan $(0.005585<0,05)$, jadi Ho ditolak dan $\mathrm{H} 1$ diterima.

5. Return on Equty (Y) berpengaruh positif signifikan terhadap Nilai Perusahaan (PBV). Dimana hasil t hitung lebih besar daripada t table $(6.455733>1,992)$ dengan nilai signifikansi $0.0000<0,05$ maka Ho ditolak dan H1 diterima.

\section{B. Saran}

Setelah memperhatikan kesimpulan penelitian diatas, penulis memberikan beberapa saran yang diharapkan dapat dipergunakan bagi penelitian-penelitian selanjutnya yang sejenis antara lain sebagai berikut:

1. Dalam menanam modal hendaknya investor tidak hanya memperhatikan terhadap kinerja keuangan, naum juga factor-faktor di luar kinerja keuangan.

2. Penelitian ini hanya melihat pengaruh Current Ratio, Debt to Equity Ratio, Total Asset Turnover, untuk beberapa periode waktu pengamatan yaitu dari tahun 2007 sampai 
dengan tahun 2016, sehingga diharapkan bagi peneliti yang tertarik untuk melakukan penelitian lebih lanjut.

3. Dalam rangka pengembangan hasil-hasil penelitian yang telah dicapai, khususnya yang berminat meneliti tentang Current Ratio (CR), Debt to Equity Ratio (DER) dan Total Asset Turnover (TATO), disarankan agar dilakukan penelitian lanjutan dengan objek penelitian lainnya pada perusahaan sejenis yang lebih banyak.

\section{DAFTAR PUSTAKA}

Agus Sartono (2014). Manajemen Keuangan Teori dan Aplikasi. Yogyakarta: BPFE

Brigham, E.F. \& Houston J.F. (2012). Dasar-Dasar Manajemen Keuangan. Jakarta: Salemba Empat.

Cahyani Nuswandari. 2009. Pengungkapan Laporan Keuangan Dalam Perspektif Signalling Theory. Jurnal. Vol 1 No.1.

Gade, M. (2005). Teori Akuntansi. Jakarta: Almahira.

Ghozali, imam. 2013. Aplikasi Analisis Multivariate Program. Semarang: Badan Penerbit Universitas Diponegoro.

Ikatan Akuntansi Indonesia. 2009. Standar Akuntansi Keuangan per 1 juli 2009. Jakarta: Salemba Empat.

Irham, Fahmi. 2012. Pengantar Manajemen Keuangan. Bandung: Alfabeta.

Jumingan. 2011. Analisis Laporan Keuangan Cetakan Pertama. Jakarta: PT. Bumi Aksara.

Kasmir. 2011. Pengantar Manajemen Keuangan. Jakarta: Kencana

Kusumajaya, Oka. "Pengaruh Struktur Modal Dan Pertumbuhan Perusahaan Terhadap Profitabilitas Dan Nilai Perusahaan. "Thesis".

Martono, dan Agus. 2008. Manajemen Keuangan, Yogyakarta: EKONISIA.

Muhammad, Eldwin. 2016. "Analisis Return on Asset, Current Ratio, Debt to Equity Ratio, Net profit Margin Terhadap Nilai perusahaan Pada Perusahaan Consumer Goods di BEI Periode 2011-2014. Universitas Syarif Hidayatullah Jakarta.

Munawir, s. 2007. Analisis Laporan Keuangan. Jogyakarta: Liberty.

Nugroho, B, S. 2012. “Analisis Pengaruh Efesiensi Modal Kerja, Likuiditas dan Solvabilitas terhadap Probabilitas". Tembalang Semarang. Jurnal Volume 1 No. 1 PT. Bursa Efek Indonesia (BEI). Indonesia Capital Market Directory (ICMD). 2007-2016. Jakarta.

Ross, Westerfield, Jordan. 2008. Pengantar Keuangan Perusahaan (Corporate Finnace Fudamental), Edisi Kedepalan, Jakarta: Salemba Empat.

Sartono, Agus, (2010). Manajemen Keuangan Teori dan Aplikasi (4th ed). Jogyakarta: Siswanto. 2016. Pengantar Manajemen. Bandung. Bumi Aksara.Stella, Yolanda. 2013

Subramanyam, K.R dan John J. Wild (2013). Analisis Laporan Keuangan. Jakarta: Salemba Empat.

Sugiyono. (2016). Metode Penelitian Kuantitatif Kualitatif dan Kombinasi (Mixed Methods). Bandung: CV Alfabeta.

Weygandt, j,j dan Donald, E, Kieso. 2013. Pengantar Akuntansi. Jakarta: Salemba Empat.

Winarno, Wahyu, Wing. 2015. Analisis Ekonometrika dan Statistika Dengan Eviews. Yogyakarta. UPP STIM YKPN 